\title{
INNOVATIVE ELEMENTS OF CULTIVATION TECHNOLOGY OF CORN HYBRIDS OF DIFFERENT FAO GROUPS IN THE CONDITIONS OF IRRIGATION
}

\section{Marchenko T. Yu.}

\section{INTRODUCTION}

Domestic scientific experience has shown that by potential of productivity of grain and green mass, forage and energy value corn is actually uncompetitive and irreplaceable in forage rations for cattle. But the methods of technological operations at present do not fully promote the realization of the yield potential of new morpho-biotypes of this crop, which is connected with insufficient compliance of agro-technologies to morphobiological features of a hybrid ${ }^{1}$.

The increase in yield of corn can be achieved through plant breeding and seed production and use of innovative hybrids. Herewith, according to many scientists, the use of micro-fertilizers and bio preparations remains an important component of agricultural intensification ${ }^{2,3,4}$.

At present, many chemical compounds have been synthesized, with the help of which it is possible to actively influence the biochemical processes in plants. Due to the small norms of application and biological origin, micronutrient fertilizers and plant growth regulators belong to the safest preparations. The issue of wide application of biologically active preparations in agriculture is paid considerable attention in the most economically developed countries $5,6,7,8,9,10,11$.

1 Лавриненко Ю. О., Нужна М. В., Боденко Н. А. Моделі гібридів кукурудзи FАO 150-490 для умов зрошення. Plant Varieties Studying and Protection. 2018. T. 14, № 1. C. 58-64. doi:10.21498/2518-1017.14.1.2018.126508.

2 Токмакова Л. М., Трепан А. О., Шевченко Л. А. Ефективність фосфорного живлення рослин кукурудзи за дії поліміксобактерину. Вісник Полтавської держсавної агарної академії. 2019. № 1. С. 73-80. doi:10.31210/visnyk2019.01.09

${ }^{3}$ Lavrynenko Y. O., Hozh O. A., Vozhegova R. A. Productivity of corn hybrids of different FAO groups depending on micro-fertilizers and growth stimulants under irrigation in the south of Ukraine. Agricultural Science and practice. 2016. No. 1. P. 55-60.

${ }^{4}$ Mason S., Kmail Z., Galusha T., Jukić Ž. Path analysis of drought tolerant corn hybrid yield and yield components across planting dates. Journal of Central European Agriculture. 2019. 20(1). P. 194-207. https://doi.org//10.5513/JCEA01/20.1.2106

5 Milander J., Jukić Ž., Mason S. Hybrid maturity influence on corn yield and yield component response to plant population in Croatia and Nebraska. Cereal Research Communications. 2017. Vol. 45, Iss. 2. P. 326-335. https://doi.org/10.1556/0806.45.2017.015 
The maximum yield of high quality corn grain is formed under condition of the optimal ratio of all structural elements - the weight of 1000 seeds, the number of grain rows in the cob, the number of grain in a row and the number of grain per cob, length and diameter of the cob. Under the insufficient development of one structural element, the yield can be compensated at the expense of other constituents. Since the individual elements of the structure are formed at different stages of organogenesis, unequal conditions for their successful development are required ${ }^{12}$.

The formation of corn plant productivity is a complicated process, which includes a number of decisive genetic factors, a number of abiotic, biotic and anthropogenic factors ${ }^{13}$. The introduction of high-yielding hybrids and effective cultivation technologies can provide a qualitatively new level of corn yield. In the recent years, the main task of its cultivation technologies remains in reduction of the gap between the actual and genetic productivity of plants ${ }^{14}$.

The aim of the research is to determine the manifestation of the plant structure indexes of modern corn hybrids of different FAO groups and find out their relationship with the grain yield under the cultivation at drip irrigation in the conditions of Southern Steppe of Ukraine. To establish the

${ }^{6}$ Irmak S., Djaman K. Effects of planting date and density on plant growth, yield, evapotranspiration, and water productivity of subsurface drip-irrigated and rainfed maize. Transactions of the ASABE. 2016. 59(5). P. 1235-1256. doi: 10.13031/trans. 59.11169

7 Котченко М. В., Кірсанова Г. В., Пугач А. М., Пугач А. В. Продуктивність різностиглих гібридів кукурудзи в умовах Північного Степу України. Вісник Полтавської державної аграрної академії. 2016. № 4. С. 27-30. doi.org/10.31210/visnyk2016.04.04

${ }^{8}$ Calvino P. A., Andradeb F. A., Sadrasb V. O. Maize yield as affected by water availability, soil depth, and crop managemen. Agronomy Journal. 2003. No. 95. 275-281.

${ }^{9}$ Troyer A. F., Background U. S. Hybrid Corn II. Crop Science. 2004. Vol. 44. No. 2, P. 370-380. doi:10.2135/cropsci 2004.3700

10 Лавриненко Ю. О., Михайленко І. В., Хоменко Т. М. Біометричні показники гібридів кукурудзи різних груп ФАО залежно від обробки мікродобривами за умов зрошення. Plant Varieties Studying and protection. 2019. Vol. 15, № 1. C. 71-79. doi.org/10.21498/2518-1017/15/1/2019/162486

${ }_{11}$ Лавриненко Ю. О., Вожегова Р. А., Гож О. А. Продуктивність гібридів кукурудзи різних груп ФАО залежно від стимуляторів росту та мікродобрив в умовах зрошення на півдні України. Вісник аграрної науки. 2016. № 7. С. 28-33.

${ }^{12}$ Гож А. А., Лавриненко Ю. А., Глушко Т. В., Лашина М. В. Агротехнологические аспекты формирования продуктивности гибридов кукурузы на орошаемых землях юга Украины. Современные энерго- и ресурсосберегающие, экологически устойчивые технологии и системы сельскохозяйственного производства. Рязань, 2014. № 11. С. 33-37.

${ }_{13}^{13}$ Сухому О. Г., Адаменко Д. М., Кравець І. С., Суханов С. В. Вплив застосування мікродобрив ТМ «Актив-харвест» на ріст, розвиток і врожайність рослин кукурудзи. Вісник Уманського національного університету садівництва. 2019. № 94(1). С. 156-164. doi.org/10.31395/2415-8240-2019-94-1-156-164

${ }_{14}^{14}$ Глушко Т. В., Войташенко Д. П. Урожайність та якість зерна кукурудзи під впливом біопрепаратів в умовах зрошення Південного Степу України. Зрошуване землеробство. 2013. № 59. С. 44-47. 
effect of micro-fertilizers on the figures of corn hybrids yields and to justify the agro-technical recommendations for the cultivation of high yields of the crop grain.

\section{Research materials and methods}

Field double-factor experiment was conducted during 2016 - 2018 on the basis of the Institute of Irrigated Agriculture, located in the South of the Steppe zone of Ukraine, namely on the right bank of the Dnipro River in Bilozerka District of Kherson region in the zone of Ingulets irrigation system array.

The experiment was settled down by using the method of randomized split plot design. The study was conducted in four replications. The sowing area of the plot was $30.0 \mathrm{~m}^{2}$, the estimated one $-20.0 \mathrm{~m}^{2}$. Factor A different by the groups of ripeness domestic hybrids of corn: DN Galateya (FAO 250), Skadovskyi (FAO 290), DN Demetra (FAO 300), Ingulskyi (FAO 350), DN Bereka (FAO 390), Chongar (FAO 420).

Factor B - treatment of corn plant with complex micronutrient fertilizers: Avatar-1, Nutrimix, which are included into the Register of allowed for the use in Ukraine pesticides. The application method - foliar fertilization at the stage of 3-5 and 7-8 leaves.

The agro-technology of corn hybrids cultivation in the experiments was generally accepted for the zone of Southern Steppe of Ukraine ${ }^{15}$. The forecrop was soybean. The sowing of corn was carried out in the first decade of May, when the soil temperature at the depth of seed wrapping was $12-14^{\circ} \mathrm{C}$.

The arable layer is within the range of $0-30 \mathrm{~cm}$. The field capacity of the soil layer is $22.0 \%$, the wilting point $-9.7 \%$ of the dry soil mass, the bulk density $-1.40 \mathrm{~g} / \mathrm{cm}^{3}$. The humus content in the arable layer of the soil is $2.2 \%$. The power of Hydrogen in the soil extraction of the upper horizons is close to neutral or weakly alkaline $(\mathrm{pH}=6.9-7.4)$, it increases by the profile. The soil is typical for the Steppe zone by its characteristics.

The main criterion for irrigation regime planning was the level of total available water (TAW). The vegetation period of corn was conditionally divided into three stages: the first - «germination - flowering», the second «flowering - milk ripeness», the third - «milk ripeness - full ripeness». The biologically optimal regime of corn irrigation was a mode in which at all stages of organogenesis TAW was maintained at the level of $80 \%$ FC.

15 Науково-практичні рекомендації з технології вирощування кукурудзи в умовах зрошення Південного Степу України. Херсон: Грінь Д.С., 2015. 104 с. 
The results of the yield evaluation were processed by the methods of ANOVA, correlation and statistical analysis with accordance to methodological recommendations ${ }^{16,17}$.

\section{Results and their discussion}

By the height of plants there was a clear ranking of the hybrids depending on the group of ripeness at the main stages of growth and development of the crop (Table. 1). The difference in this index between middle-early (FAO 200-290), middle (FAO 300-390), and middle-late (FAO 400-490) hybrids has already been observed at the stage of 12-13 leaves, but the most significant $(12-24 \mathrm{~cm})$ it was at the stage of cobs flowering and milk ripeness of grain. In general, the difference in the plant height between the hybrids for ripeness groups is fully anticipative and does not contradict the general biological position.

Corn plants treatment with micronutrients positively affected the height of plants of the hybrids in all the estimated stages of the growth and development of the crop. The greatest impact on the growth processes was caused by an Avatar-1 preparation, which ensured the increase in the plant height, in comparison to the untreated control, by 1-7 cm. The use of micronutrient fertilizers Nutrimix, in general by the variants of the experiment, had the minimum effect on the growth processes (increase by the growth and development stages of the crop was $1-3 \mathrm{~cm}$ ).

The analysis of the height formation of the corn plants depending on the FAO group and the effects of micronutrient fertilizers has a valuable utilitarian value in the combination with the grain yields and the determination of the optimum biometric parameters of corn hybrids by some FAO groups.

Among the studied hybrids, the largest plant height in all the stages of development was in the middle-late hybrid Chongar (FAO 420) with the maximum at the stage of milk ripeness under the treatment with Avatar-1 $267 \mathrm{~cm}$. It is determined that between the height of the plants, the height of the cob setting, the area of the assimilation surface and the grain yield of hybrids there is a close correlation at the level $r=+0.873 ;+0.745$, and +0.883 , respectively, which testifies about the possibility of preliminary visual assessment on these features of the productivity in the field conditions.

16 Вожегова Р. А., Лавриненко Ю. О., Малярчук М. П. Методика польових і лабораторних досліджень на зрошуваних землях. Херсон: Грінь Д.С., 2014. 286 с.

17 Ушкаренко В. О., Нікішенко В. Л., Голобородько С. П., Коковіхін С. В. Дисперсійний і кореляційний аналіз результатів польових дослідів Херсон: Айлант, 2009. $372 \mathrm{c}$. 
Table 1

The height of the plants and the height of the cob setting in the hybrids of corn depending on the ripeness group and treatment with micronutrients (average for 2016-2018)

\begin{tabular}{|c|c|c|c|c|c|}
\hline \multirow{2}{*}{$\begin{array}{l}\text { Hybrid - } \\
\text { factor A }\end{array}$} & \multirow{2}{*}{$\begin{array}{c}\text { Micronutrient } \\
\text { Fertilizers - factor B }\end{array}$} & \multicolumn{3}{|c|}{$\begin{array}{c}\text { Plant height }(\mathrm{cm}) \text { according to } \\
\text { the growth stages and the crop } \\
\text { development }\end{array}$} & \multirow{2}{*}{$\begin{array}{l}\text { The height } \\
\text { of the cob } \\
\text { setting, cm }\end{array}$} \\
\hline & & $\begin{array}{l}12-13 \\
\text { leaves }\end{array}$ & $\begin{array}{l}\text { Flowerin } \\
\mathrm{g} \text { of cobs }\end{array}$ & $\begin{array}{c}\text { Milk } \\
\text { ripeness }\end{array}$ & \\
\hline \multirow{3}{*}{$\begin{array}{l}\text { DN Galateya } \\
\text { (FAO 250) }\end{array}$} & $\begin{array}{l}\text { Without treatment - } \\
\text { control }\end{array}$ & 148 & 239 & 242 & 104 \\
\hline & Avatar-1 & 154 & 243 & 246 & 105 \\
\hline & Nurtrimix & 152 & 241 & 245 & 105 \\
\hline \multirow{3}{*}{$\begin{array}{l}\text { Skadovskyi } \\
\text { (FAO 290) }\end{array}$} & $\begin{array}{l}\text { Without treatment - } \\
\text { control }\end{array}$ & 144 & 232 & 237 & 101 \\
\hline & Avatar-1 & 146 & 233 & 239 & 102 \\
\hline & Nurtrimix & 145 & 232 & 238 & 102 \\
\hline \multirow{3}{*}{$\begin{array}{l}\text { DN Demetra } \\
\text { (FAO 300) }\end{array}$} & $\begin{array}{l}\text { Without treatment - } \\
\text { control }\end{array}$ & 150 & 244 & 252 & 94 \\
\hline & Avatar-1 & 158 & 248 & 254 & 98 \\
\hline & Nurtrimix & 155 & 246 & 254 & 96 \\
\hline \multirow{3}{*}{$\begin{array}{l}\text { Ingulskyi } \\
\text { (FAO 350) }\end{array}$} & $\begin{array}{l}\text { Without treatment - } \\
\text { control }\end{array}$ & 153 & 243 & 250 & 105 \\
\hline & Avatar-1 & 160 & 248 & 254 & 107 \\
\hline & Nurtrimix & 155 & 246 & 253 & 106 \\
\hline \multirow{3}{*}{$\begin{array}{l}\text { DN Bereka } \\
\text { (FAO 390) }\end{array}$} & $\begin{array}{l}\text { Without treatment - } \\
\text { control }\end{array}$ & 151 & 246 & 254 & 116 \\
\hline & Avatar-1 & 161 & 256 & 261 & 118 \\
\hline & Nurtrimix & 153 & 248 & 255 & 117 \\
\hline \multirow{3}{*}{$\begin{array}{l}\text { Chongar } \\
\text { (FAO 420) }\end{array}$} & $\begin{array}{l}\text { Without treatment - } \\
\text { control }\end{array}$ & 158 & 254 & 261 & 126 \\
\hline & Avatar-1 & 162 & 256 & 267 & 128 \\
\hline & Nurtrimix & 161 & 255 & 264 & 127 \\
\hline \multirow{3}{*}{\multicolumn{2}{|c|}{$\begin{array}{l}\mathrm{LSD}_{05} \text { Factor } \mathrm{A} \\
\text { Factor } \mathrm{B} \\
\text { Interaction of } \mathrm{AB}\end{array}$}} & 2.94 & 3.12 & 2.29 & 2.18 \\
\hline & & 3.15 & 4.12 & 3.13 & 3.12 \\
\hline & & 3.18 & 4.25 & 3.11 & 3.19 \\
\hline
\end{tabular}

The results of the ANOVA found out that the greatest influence on the plant height had a hybrid composition - the share of influence was $65.2 \%$.

This confirms the preliminary conclusion that the main factor of grain yields is a group of hybrid ripeness, and the plant height indirectly affects the grain yield of the hybrids due to the potential productivity of the genotypes with a longer FAO.

The treatment with regulating preparations had less effect on the plant height $-31.8 \%$. The interaction of the studied factors is insignificant $-2.5 \%$ and the index of the residual action were not significant. 
One of the parameters of technological appropriateness of corn hybrids is the height of the productive (upper) cob setting, because its low location leads to significant losses during harvesting. The height of the cob setting was changed in a rather wide range - from 94 to $129 \mathrm{~cm}$ (Table 1). The highest location was in the middle-late hybrid and the lowest - in the middle-ripening hybrid DN Demetra. Micro-fertilizers increased the height of the cob setting - by $1-3 \mathrm{~cm}$.

For the optimum photosynthesis process, corn crops should have a certain area of leaf surface, which serves as a means of the accumulation of plastic substances for the formation of grain yield of the hybrids. In the conditions of irrigation, the intensity of physiological processes of corn intensifies - the area and productivity of leaves and water content and dry matter in the leaves increases.

The conducted researches found out that the increase of the leaf area surface per plant of corn increased significantly with the growth and development of the plants. At the beginning of vegetation of plants, the area of leaf surface was almost the same at all the investigated variants, however, at the stage of $12-13$ it leaves was noted a significant increase of this parameter, on average, by 6.7-8 times, compared to the similar parameters at the stage of 7 leaves. The largest indexes of the leaf area, on the control variant, on average, by the Factor A (hybrids) $-0.421 \mathrm{~m}^{2}$ had the plants of middle-late corn hybrids. The ripeness group of hybrids caused fluctuations in the leaf surface area, which at the stage of 12-13 leaves was the highest on the plots with the middle-late hybrid Chongar and was, on average by the Factor A (hybrid), $0.424 \mathrm{~m}^{2}$. On the other hybrids the index decreased on average by $3.3-10.2 \%$ compared with the hybrid Chongar. The maximum value of the leaf surface area on all the variants has been observed at the cobs flowering stage. The highest this index was at the middle-late hybrid Chongar under the use of Avatar-1 and averaged to $0.668 \mathrm{~m}^{2}$ per plant. The least leaf surface area was formed on the hybrids of early-ripening group Skadovskyi $\left(0.481 \mathrm{~m}^{2}\right.$ per plant $)$ and DN Galateya $\left(0.451 \mathrm{~m}^{2}\right)$ on the variants without the use of preparations. In this period, all the hybrids of corn had the highest indexes of the leaf surface area. In the next stages of the plants of the crop slightly decreased. So, at the stage of milk grain ripeness the area of the leaf surface, on average by the hybrids, averaged to $0.441 \mathrm{~m}^{2}$ in the middleearly group, $0.537 \mathrm{~m}^{2}$ in the middle-ripening group, $0.627 \mathrm{~m}^{2}$ per plant in the middle-late group of the hybrids.

Treatment of corn with micronutrients positively affected the dynamics of the leaf surface area of the hybrids by the individual stages of development. The greatest impact on the leaf surface area was caused by the 
preparation Avatar-1, which provided the additional growth by the individual developmental stages, compared to the control, by $0.029-0.048$ $\mathrm{m}^{2}$. Micronutrient fertilizer Nutrimix, on average by the experiment, had the minimal influence on the area of leaf surface (increase of $0.018-0.029 \mathrm{~m}^{2}$ per plant by the stages of development).

The accumulation of organic matter and yield correlates with the area and the activity of the leaf apparatus, its capacity to accumulate solar energy. This is confirmed by the calculations of the polynomial dependence of the area of the leaf surface of the plants of hybrids and grain yield (Fig. 1).

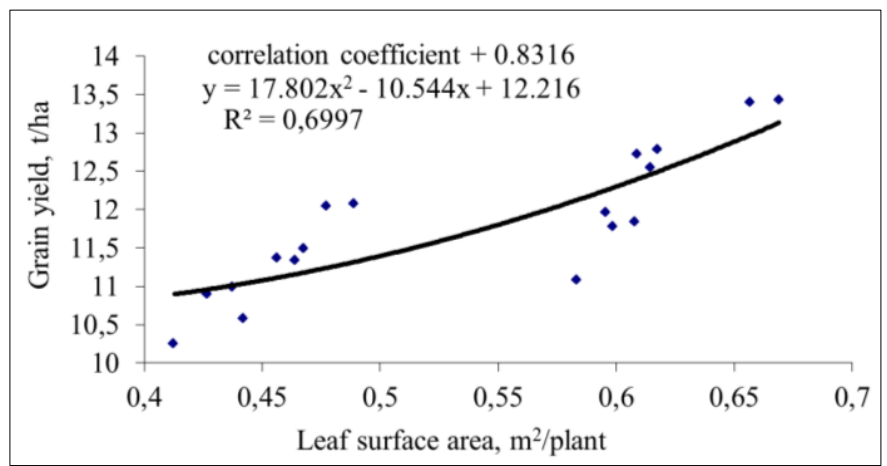

Fig. 1. Polynomial trend line of the dependence of the area of leaf surface of the plants of corn hybrids and grain yields (2016-2018)

Treatment of corn with micronutrients positively affected the dynamics of the area of leaf surface of the hybrids by individual developmental stages. The greatest influence on the leaf surface area was caused by the preparation Avatar-1, which provided the additional growth by the individual stages of development, compared to the control, by $7-11 \%$. Micronutrient fertilizer Nutrimix, on average by the study, had the minimal influence on the area of leaf surface (the increase by $4-9 \%$ ) by the individual stages of development.

Accumulation of raw and dry herbage mass of corn plants are important characteristics of corn plants, which play significant role in the process of the productivity formation of modern corn hybrids. These indexes are physiologically connected with the group of ripeness of hybrids, which indirectly affects the grain yield. At the treatment of corn crops with the preparation Avatar-1, we received the largest increase in raw herbage mass in all the studied hybrids. At this variant of treatment, the highest green mass rates in the hybrids of middle-early group averaged to $3.40-50.73 \mathrm{t} / \mathrm{ha}$, the 
middle-ripening group - 3.65-53.03, the middle-late hybrid Chongar 3.88-54.71 t/ha, depending on the stage of development.

At the stage of physiological maturity, there is a decrease of green mass yield on all the variants, which is explained by the redistribution of plastic substances from vegetative bodies to reproductive, mainly, for the formation of grain. The greatest value of the green mass outlet is $37.19 \mathrm{t} / \mathrm{ha}$ fixed in the hybrid Chongar (Fig. 2).

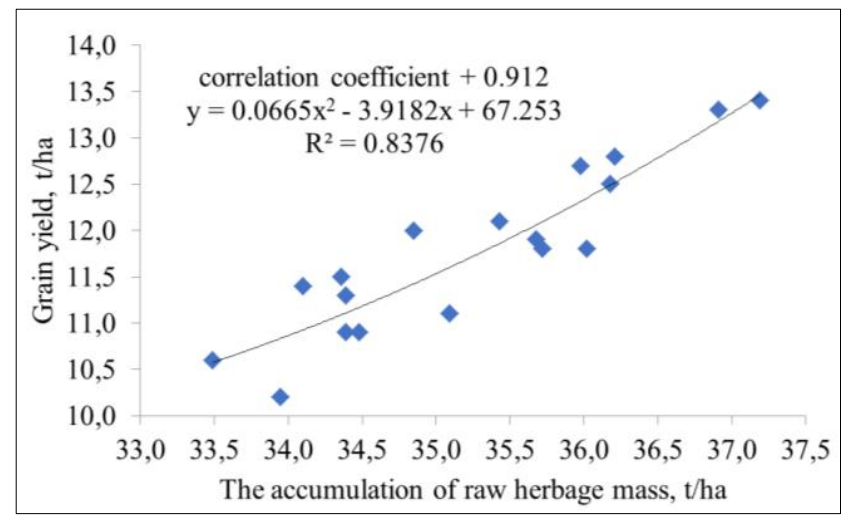

Fig. 2. Polynomial trend line of the dependence of raw herbage mass of corn hybrids at the stage of physiological ripeness and grain yield (2016-2018)

It was established that there is a high positive correlation between the accumulation of dry herbage mass and grain yield of the hybrids. Thus, at the stage of physiological ripeness, correlation coefficient between the accumulation of dry herbage mass and grain yields of the hybrids was + 0.863 .

The data concerning the accumulation of herbage mass of the corn plants testify that the hybrids with a longer period of vegetation and more productive ones form considerably more both raw and dry matter.

Determination of the influence on the indexes of the accumulation of dry mass of the hybrid composition showed that the least level of dry mass accumulation was at the cultivation of middle-early hybrids Skadovskyi and DN Galateya where dry herbage mass at the stage of physiological ripeness fluctuated within 19.25-20.81 t/ha. Application of the preparation Avatar-1 provided the gain of dry mass by $6.9-7.1 \%$ in these hybrids. The use of the preparation Nutrimix provided the gain of dry mass by $6.0-6.2 \%$. The 
maximum values of dry mass are fixed in the hybrids DN Bereka and Chongar -21.63 and $21.83 \mathrm{t} / \mathrm{ha}$. However, they had the minimum increase of the dry mass due to the action of micro-fertilizers that constituted 0.6-1.2\% (Nutrimix) and 2.0-2.1\% (Avatar-1). The growth of the group of ripeness by FAO from 290 to 420 provided the increase in the accumulation of dry mass by $10.0-11.2 \%$ (Fig. 3).

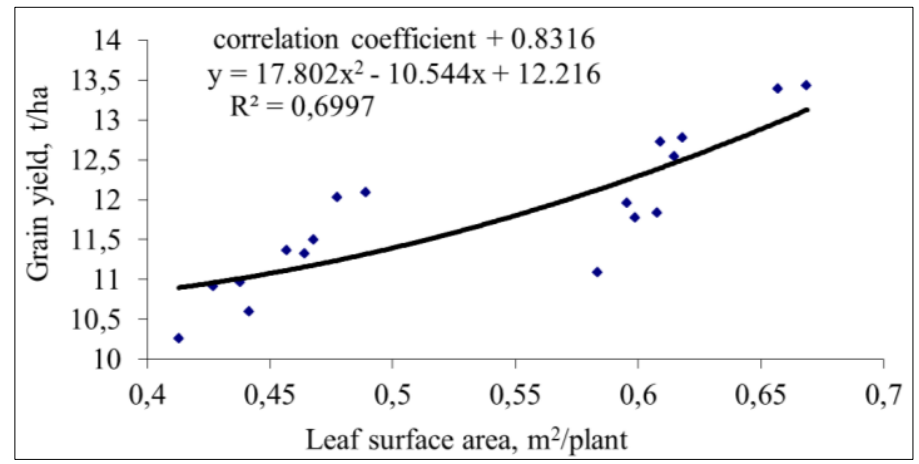

Fig. 3. Polynomial trend line of the dependence of dry herbage mass of corn hybrids and yield at the stage of physiological maturity (2016-2018)

The formation of high yield of high-quality corn grain is caused by the main structural elements, which include the weight of 1000 seeds, the number of grain rows, the number of grains in a row, the number of grains per cob, the length and diameter of the cob.

The studied hybrids revealed the peculiarities of formation of the elements of crop structure, depending on a group of ripeness and treatment with micronutrients. The size of the ears, which were formed on the corn plants, was typical for a particular type of hybrid (Table. 2).

At the determination of the length of the cobs, we took under consideration only its part with grain. By the results of biometric measurements, the least average length of the cob was determined in the middle-early hybrid DN Galateya - 16.8-17.3 cm. With the increase of the FAO group, an index of the length of the cob was increased, due to the hybrids characteristic. Thus, the value of this index for the hybrid Skadovskyi, on average for the period of observations during 2016-2018, was $17.8-18.5 \mathrm{~cm}$; for the middle-ripening hybrids DN Demetra - 18.4-19.0 cm and Ingulskyi - 17.2-17.9 cm, DN Bereka-19.4-20.1 cm. The highest value of the index was determined in the middle-late hybrid Chongar $-20.3-22.6 \mathrm{~cm}$. 
Table 2

Indexes of the yield structure of corn hybrids of different groups of ripeness depending on the treatment with micronutrients (average for 2016 - 2018)

\begin{tabular}{|c|c|c|c|c|c|c|}
\hline $\begin{array}{c}\text { Factor A, } \\
\text { Hybrid }\end{array}$ & $\begin{array}{l}\text { Factor in, } \\
\text { Treatment of } \\
\text { micronutrient } \\
\text { Fertilizerm }\end{array}$ & $\begin{array}{c}\text { The } \\
\text { length of } \\
\text { the cob, } \\
\text { CM }\end{array}$ & $\begin{array}{l}\text { Diamete } \\
\text { r of the } \\
\text { cob, } \\
\text { mm }\end{array}$ & $\begin{array}{c}\text { Number } \\
\text { of grain } \\
\text { rows }\end{array}$ & $\begin{array}{c}\text { Grain } \\
\text { weight } \\
\text { from cob, } \\
\mathrm{g}\end{array}$ & Yield, t/ha \\
\hline \multirow{3}{*}{$\begin{array}{c}\text { DN Galateya } \\
\text { (FAO 250) }\end{array}$} & Without & 16.8 & 39.9 & 15.2 & 154.6 & 10.3 \\
\hline & Avatar-1 & 17.3 & 41.4 & 15.8 & 158.3 & 10.9 \\
\hline & Nurtrimix & 17.1 & 40.7 & 15.4 & 156.9 & 10.9 \\
\hline \multirow{3}{*}{$\begin{array}{l}\text { Skadovskyi } \\
\text { (FAO 290) }\end{array}$} & Without & 17.9 & 43.8 & 14.6 & 169.4 & 10.6 \\
\hline & Avatar-1 & 18.5 & 44.6 & 15.3 & 173.2 & 11.5 \\
\hline & Nurtrimix & 18.3 & 44.1 & 15.1 & 172.0 & 11.4 \\
\hline \multirow{3}{*}{$\begin{array}{c}\text { DN Demetra } \\
\text { (FAO 300) }\end{array}$} & Without & 18.4 & 47.8 & 18.0 & 173.5 & 11.3 \\
\hline & Avatar-1 & 19.0 & 48.2 & 18.4 & 185.3 & 12.1 \\
\hline & Nurtrimix & 18.7 & 47.9 & 18.1 & 181.8 & 12.0 \\
\hline \multirow{3}{*}{$\begin{array}{l}\text { Ingulskyi } \\
\text { (FAO 350) }\end{array}$} & Without & 17.2 & 35.6 & 14.3 & 167.8 & 11.1 \\
\hline & Avatar-1 & 17.9 & 37.2 & 14.7 & 180.1 & 11.8 \\
\hline & Nurtrimix & 17.6 & 38.5 & 14.4 & 179.3 & 11.8 \\
\hline \multirow{3}{*}{$\begin{array}{l}\text { DN Bereka } \\
(\text { FAO 390) }\end{array}$} & Without & 19.4 & 41.9 & 14.9 & 276.4 & 11.9 \\
\hline & Avatar-1 & 20.1 & 44.3 & 15.8 & 282.6 & 12.8 \\
\hline & Nurtrimix & 19.7 & 43.0 & 15.2 & 280.9 & 12.7 \\
\hline \multirow{3}{*}{$\begin{array}{l}\text { Chongar } \\
\text { (FAO 420) }\end{array}$} & Without & 20.3 & 50.6 & 18.5 & 278.0 & 12.5 \\
\hline & Avatar-1 & 22.6 & 52.4 & 19.1 & 289.7 & 13.4 \\
\hline & Nurtrimix & 21.1 & 51.8 & 18.6 & 285.8 & 13.3 \\
\hline \multirow{3}{*}{$\mathrm{LSD}_{05}$} & Factor A & 0.42 & 0.85 & 0.12 & 5.21 & 0.4 \\
\hline & Factor B & 0.35 & 0.96 & 0.18 & 6.14 & 0.6 \\
\hline & Interaction of & 0.29 & 0.79 & 0.10 & 4.99 & 0.5 \\
\hline
\end{tabular}

Providing of the corn plants with microelements for growth and development has caused the increase of biometric indexes of the cobs. Larger values of the cob length were under the use of micro-fertilizers Nutrimix and Avatar-1, when the increase was, in comparison to the control, 2.5 and $4.9 \%$, respectively.

The index of the diameter of the cob has not almost changed under the influence of the studied factors, but it depended on the genotypical features of the hybrids and averaged, for the 2016-2018 period, for the hybrid DN Galateya - 39.9-41.4 mm, for the hybrid Skadovskyi - 43.8-44.6 mm, for hybrid DN Demetra - 47.8-48.2 mm, Ingulskyi - 35.6-38.5 cm, and DN Bereka - 41.9-44.3 mm. The greatest value of the index - the diameter of the cob - was observed in the middle-late hybrid Chongar - 50.6-52.4 mm.

By the results of the measurements, it was established that the use of micronutrient fertilizers Nutrimix, Avatar-1 contributed to the stable increase in the length and diameter of the cobs of the corn hybrids of different FAO groups. Thus, in the areas where micro-fertilizers were applied, in comparison to the untreated control, the increase reached the 
value for the cob length of 2.5-4.9\% $(0.45-0.9 \mathrm{~cm})$ and for the diameter of $2.3-3.2 \%(1.0-1.4 \mathrm{~mm})$.

The number of the grain rows increased mainly with the increase of the FAO group. Thus, on the control variants without treatment the number of grain rows, on average for the years of the study, reached 15.9, in the group of middle-early hybrids averaged to 14.9 in the group of middle-ripening 15.7, in the middle-late ripening hybrid Chongar the number of grain rows was 18.5 .

The same regularity was in the mass of grain per cob. On the variant without treatment with micro-fertilizers, the maximum values of the mass of grain per cob was observed in the middle-late hybrid Chongar on the control variant $-278.0 \mathrm{~g}$. By the middle-early ripening group of FAO, the mass of grain per cob was $162.0 \mathrm{~g}$, by the middle-ripening - $205.9 \mathrm{~g}$. The use of micro-fertilizers had a little less impact, compared to the group of FAO, but on average by the factor, the treatment with micronutrient fertilizers Nutrimix and Avatar-1 increased the productivity by $2.0-8.3 \mathrm{~g}$, or by $0.7-3.8 \%$. The maximum values of grain weight per cob was on the variants with the application of micro-fertilizer Avatar-1 and constituted, on average by all the FAO groups $-211.5 \mathrm{~g}$ that is more by $3.8 \%$ than the control and by $1 \%$ in comparison to the treatment with Nutrimix.

Modeling between the yields of corn and grain weight per cob allowed determining significant difference between the studied hybrids and micronutrient fertilizers treatment. The correlation coefficient in this case is +0.864 .

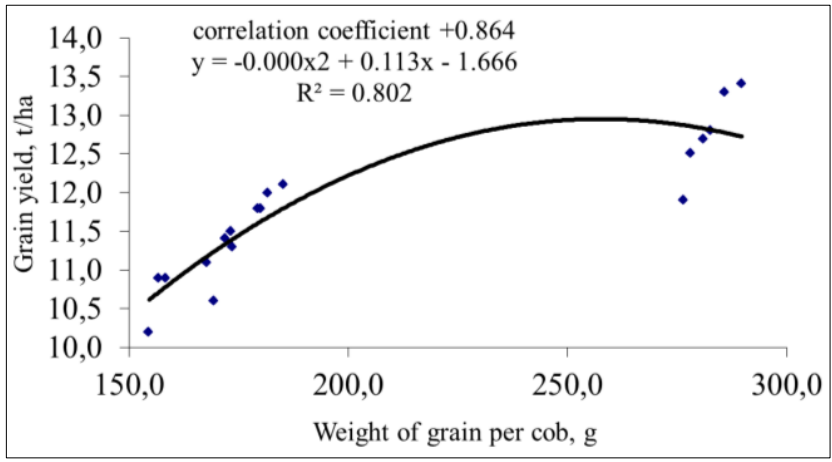

Fig. 4. Polynomial trend line of the grain weight per cob of the corn hybrids and grain yields, 2016-2018 
The study of the correlation dependence between the yields and other major economically valuable features is of practical importance for the determination of optimal parameters in the process of development of corn hybrids agricultural technology for the cultivation of them in the specific agro-climatic zones.

By the analysis of correlation dependencies between the indexes of the structure and the yield of corn grain, a high tie was established. Thus, the correlation coefficient between the grain yield and the length of the cob was $\mathrm{r}=+0.915$, the diameter of the cob $\mathrm{r}=+0.624$, the number of grain rows $r=+0.581$ and the weight of grain per cob $r=+0.864$.

According to the conducted simulation it was proved that the length of the cob of the corn hybrids is significantly affected by the yield of grain. The maximum yield of corn grain is formed in the hybrids with the length of the cob more than $22 \mathrm{~cm}$ (Fig. 4).

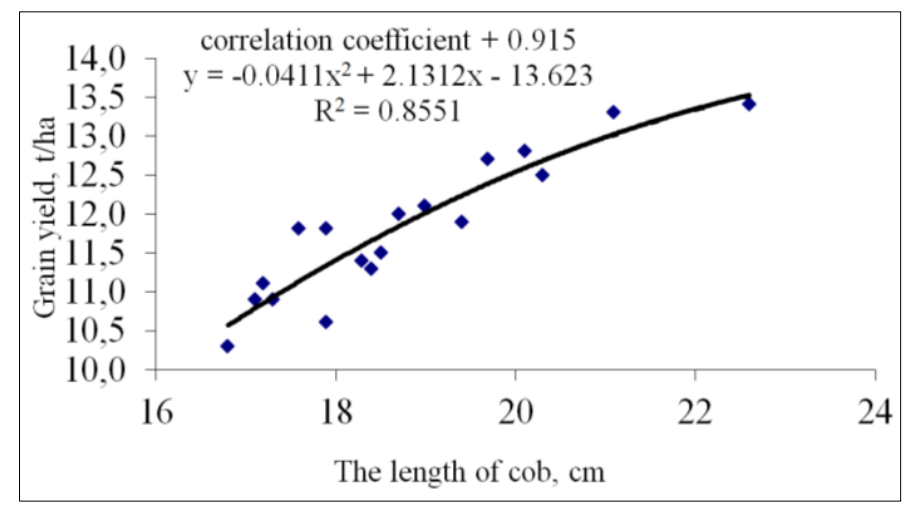

Fig. 5. Polynomial trend line of the length of the cob of the corn hybrids and the yield of grain, 2016-2018

The diameter of the cob had less effect on the grain yield of the hybrids. The maximum yield was formed at the diameter of the cob of 50-55 mm. 


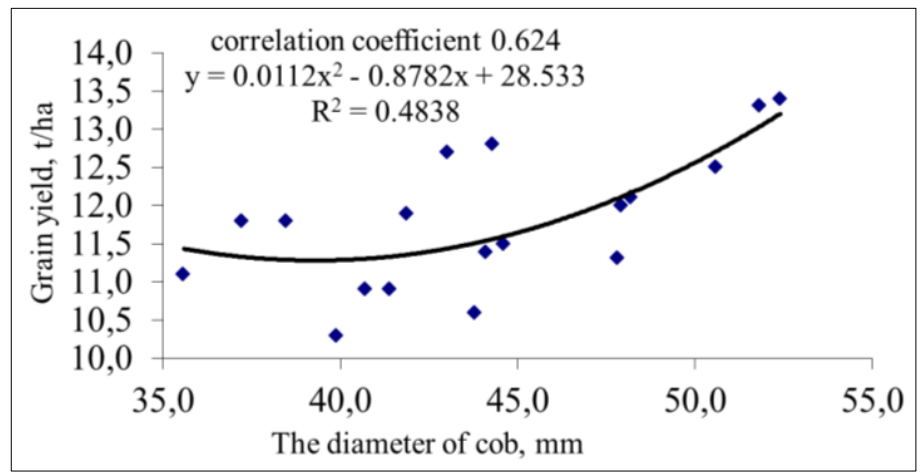

Fig. 6. Polynomial trend line of the diameter of the cob of the corn hybrids and the yield of grain, 2016-2018

The correlation between the yields of corn grain and grain mass per cob allowed determining significant difference between the studied hybrids. The correlation coefficient was +0.864 .

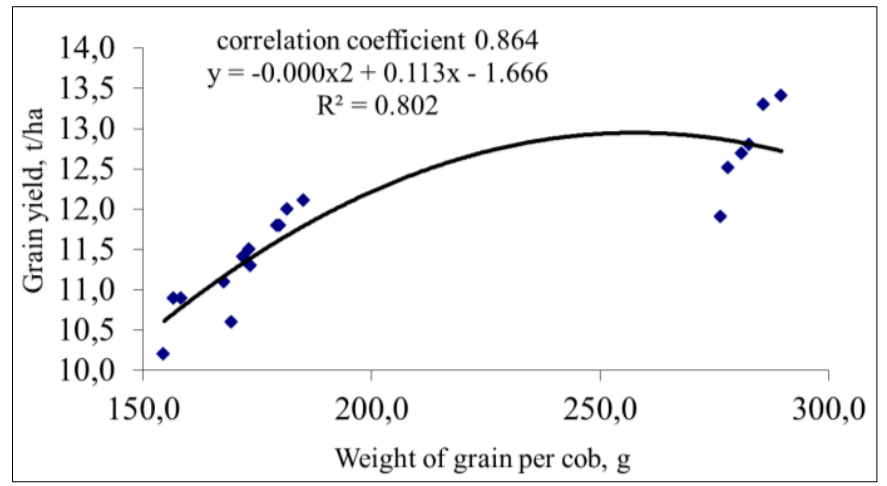

Fig. 7. Polynomial trend line of the grain weight per cob of the corn hybrids and the grain yields, 2016-2018

Weight of 1000 seeds is one of the most important indexes of the corn structure, which effects the formation of high productivity.

In our researches, this index fluctuated under the influence of the studied factors, but their influence was not equal (Table. 3). 
Table 3

Weight of 1000 seeds of the corn hybrids of different groups by FAO depending on the treatment with micronutrient fertilizers, $g$ (average for 2016-2018)

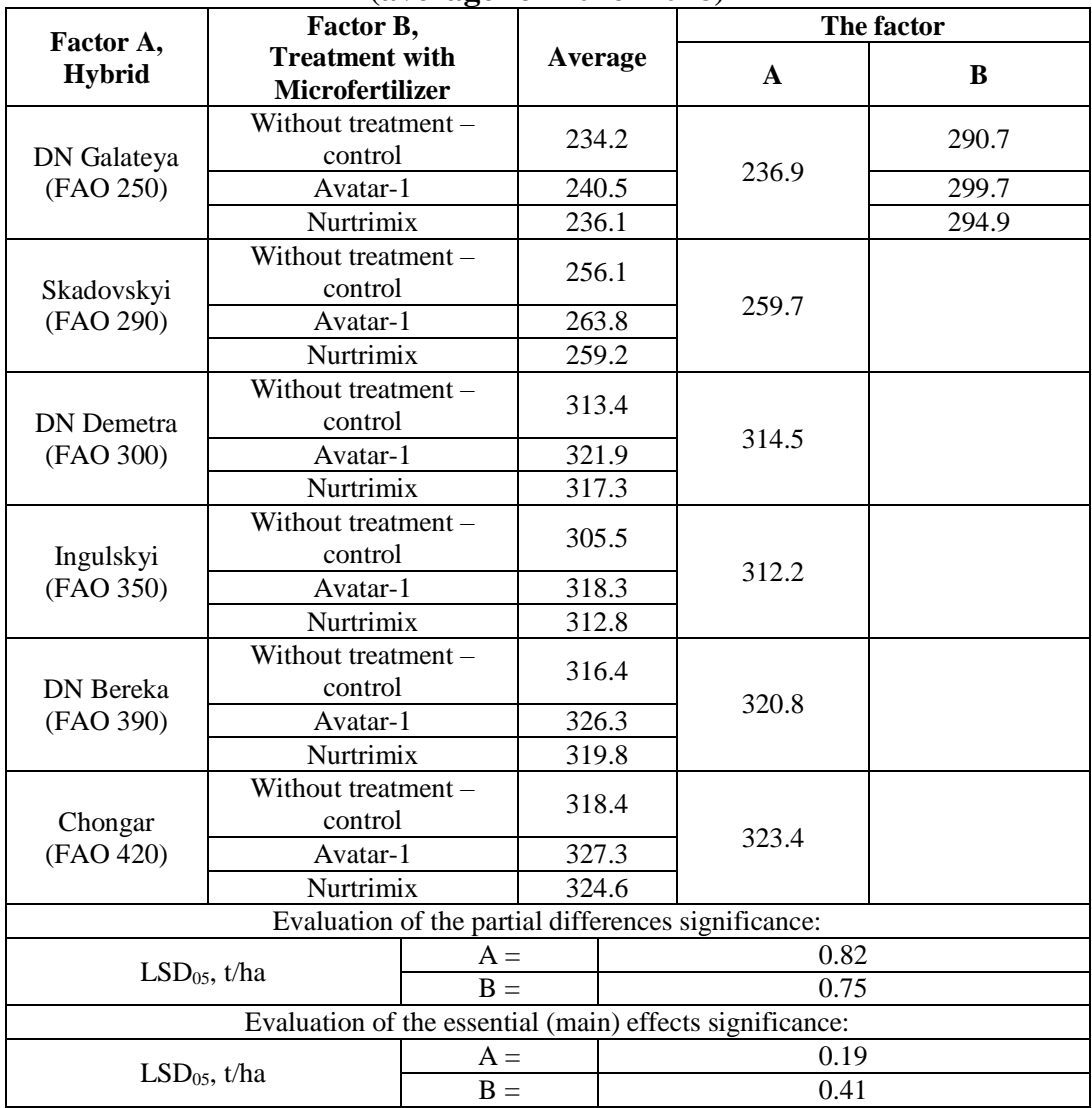

Weight of 1000 corn seeds in the studies fluctuated depending on the studied factors. The use of micro-fertilizers treatment helped to increase the weight of 1000 seeds, but the most influence on the weight of 1000 seeds had the group of ripeness of hybrid. The value of this index in the middleearly group averaged at the treatment with micro-fertilizer Avatar-1 and Nutrimix to 252.2 and $247.7 \mathrm{~g}$, respectively. At the application of microfertilizers, on average, this index was higher by $4.2-9.0 \mathrm{~g}$, compared to the untreated control. 
The performed analysis showed that the weight of 1000 corn seeds in different groups of FAO fluctuated within 234.2-327.3 g. The least weight of 1000 seeds - $234.2 \mathrm{~g}$ was formed at the sowing of the hybrid DN Galateya without the treatment with micronutrient fertilizers. The highest average weight of 1000 seeds (in the control variant) was defined in the hybrid Chongar $-318.4 \mathrm{~g}$.

Among the middle-ripening group of hybrids, the biggest weight of 1000 seeds had the hybrid DN Bereka - 316.4 g. At the treatment with the preparation Avatar-1, the weight of 1000 seeds increased by $3.1 \%$.

The maximum weight of 1000 seeds, on average for the years of the study (327.3 g), was received at the sowing of the hybrid Chongar at the treatment with micro-fertilizer Avatar-1.

The analysis of the obtained experimental data showed that there is a close tie between the indexes of yield and weight of 1000 seeds of the corn hybrids of different groups of ripeness. The correlation coefficient was 0.805 .

\section{CONCLUSIONS}

It was determined that between the height of plants, the height of the cob setting, the area of the assimilation surface and the grain yield of the hybrids there is a tight correlation at the level $r=0.873 ; 0.745$ and 0.883 , respectively, which may indicate the possibility of previous visual evaluation of these parameters on the productivity in the field.

The ratio of the plant height of the hybrids by the ripeness groups and the yield level showed that for the middle-early group (FAO 200-290) at the stage of the linear growth cessation the optimal plant height is $240-250 \mathrm{~cm}$, the grain yield in this case is $11.2-11.5 \mathrm{t} / \mathrm{ha}$; for the middle-ripening group (FAO 300-390) - $255 \mathrm{~cm}$ with the grain yield at the level of $11.8-12.1 \mathrm{t} / \mathrm{ha}$; for the middle-late hybrids (FAO 400-490) the optimum plant height to ensure the highest grain yield (more than $13 \mathrm{t} / \mathrm{ha}$ ) is in the range from 265 to $270 \mathrm{~cm}$. The optimum height of the plants and the maximum yields can be achieved in the irrigated conditions at the use of the corn hybrids of the relevant group of ripening and the use of complex micro-fertilizers.

Treatment of the corn plants with fertilizers had a positive effect on the dynamics of the assimilation surface area of the hybrids by the stages of growth and development of the plants. The greatest influence on the assimilation surface area was caused by the preparation Avatar-1, which provided the increase at certain stages of the development, compared to the untreated control, at the level of $0.029-0.048 \mathrm{~m}^{2} /$ plant. 
Treatment of the corn with micronutrients had a positive effect on the accumulation of the raw herbage mass of the hybrids, by the certain stages of development. Among the studied hybrids, the maximum indexes of the raw herbage accumulation were observed in the middle-late hybrid Chongar (FAO 420) in the case of a use of the complex micro-fertilizer Avatar-1, and by the stages of development it increased up to $54.71 \mathrm{t} / \mathrm{ha}$ in the milk ripeness stage. It was determined that between the accumulation of raw herbage mass, dry herbage mass and the grain yield of the hybrids there is a tight correlation at the level of $+0.912,+0.863$, which may indicate the possibility of a preliminary evaluation of these parameters of productivity in the field conditions.

The study showed that treatment with micronutrients affects the formation of the elements of the structure of corn grain yield. The highest indexes of all the structural elements were observed at the sowing of the hybrids of middle and middle-late FAO group under the treatment with micro-fertilizer Avatar-1. The maximum values of the indexes of the cob structure and yield were observed in the hybrid Chongar, treated with the micro-fertilizer Avatar-1.

The optimum of the cob structure indexes of the plants and the maximum yield could be achieved in the irrigated conditions at the use of the corn hybrids of the relevant groups of ripeness and complex micro-fertilizers.

\section{SUMMARY}

The article presents the results of the researches on the definition of innovative elements of cultivation technology for corn hybrids of different FAO groups in the conditions of irrigation. The manifestation of biometric characteristics of the corn hybrids of different FAO groups is studied, and their connection with the grain yield was found out when cultivating them at drip irrigation in Southern Steppe of Ukraine. The effect of micro-fertilizers on the dynamics of biometric parameters of the corn hybrids plants was determined.

The manifestation of the indexes of the plant structure of modern corn hybrids of different FAO groups was defined and their connection with the yield of grain was elucidated. The influence of micro-fertilizers on the indexes of the corn hybrids yield and reasonable agro-technical recommendations for obtaining high grain yields of the crop were determined.

The correlation dependence between the yields and other major economically valuable features, which have practical significance for the determination of the optimal parameters in the process of the cultivation 
technology development for the corn hybrids for specific agro-climatic zones, was studied.

The optimum of the structure of the cob of the crop and the maximum yield could be achieved in the irrigated conditions through the use of the corn hybrids of relevant ripeness groups and complex micro-fertilizers.

\section{REFERENCES}

1. Лавриненко Ю. О., Нужна М. В., Боденко Н. А. Моделі гібридів кукурудзи FАO 150-490 для умов зрошення. Plant Varieties Studying and

Protection. 2018. T. 14, № 1. C. 58-64. doi:10.21498/25181017.14.1.2018.126508.

2. Токмакова Л. М., Трепан А. О., Шевченко Л. А. Ефективність фосфорного живлення рослин кукурудзи за дії поліміксобактерину. Вісник Полтавської державної агарної академії. 2019. № 1. С. 73-80. doi:10.31210/visnyk2019.01.09

3. Lavrynenko Yu. O., Hozh O. A., Vozhegova R. A. Productivity of corn hybrids of different FAO groups depending on microfertilizers and growth stimulants under irrigation in the south of Ukraine. Agricultural science and practice. 2016. № 1. P. 55-60.

4. Mason S., Kmail Z., Galusha T., Jukić Ž. Path analysis of drought tolerant maize hybrid yield and yield components across planting dates. Journal of Central European Agriculture. 2019. 20(1). P. 194-207. https://doi.org//10.5513/JCEA01/20.1.2106

5. Milander J., Jukić Ž., Mason S. Hybrid maturity influence on maize yield and yield component response to plant population in Croatia and Nebraska. Cereal Research Communications. 2017. Vol. 45, Iss. 2. P. 326-335. https://doi.org/10.1556/0806.45.2017.015

6. Irmak S., Djaman K. Effects of planting date and density on plant growth, yield, evapotranspiration, and water productivity of subsurface dripirrigated and rainfed maize. Transactions of the ASABE. 2016. 59(5). P. 1235-1256. doi: 10.13031/trans.59.11169

7. Котченко М. В., Кірсанова Г. В., Пугач А. М., Пугач А. В. Продуктивність різностиглих гібридів кукурудзи в умовах Північного Степу України. Вісник Полтавської державної аграрної академії. 2016. № 4. C. 27-30. doi.org/10.31210/visnyk2016.04.04

8. Calvino P. A., Andradeb F. A., Sadrasb V. O. Maize Yield as Affected by Water Availability, Soil Depth, and Crop Managemen. Agronomy Journal. 2003. № 95. 275-281.

9. Troyer A. F., Background U. S. Hybrid Corn II. Crop Science. 2004. Vol. 44. No. 2, P. 370-380. doi:10.2135/cropsci2004.3700

10. Лавриненко Ю. О., Михайленко І. В., Хоменко Т. М. Біометричні показники гібридів кукурудзи різних груп ФАО залежно від 
обробки мікродобривами за умов зрошення. Plant Varieties Studying and protection. 2019. Vol. 15, № 1. C. 71-79. doi.org/10.21498/2518$1017 / 15 / 1 / 2019 / 162486$

11. Лавриненко Ю. О., Вожегова Р. А., Гож О. А. Продуктивність гібридів кукурудзи різних груп ФАО залежно від стимуляторів росту та мікродобрив в умовах зрошення на півдні України. Вісник аграрної науки. 2016. № 7. C. 28-33.

12. Гож А. А., Лавриненко Ю. А., Глушко Т. В., Лашина М. В. Агротехнологические аспекты формирования продуктивности гибридов кукурузы на орошаемых землях юга Украины. Современные энерго- и ресурсосберегающие, экологически устойчивые технологии и системы сельскохозяйственного производства. Рязань, 2014. № 11. С. 33-37.

13. Сухому О. Г., Адаменко Д. М., Кравець I. С., Суханов С. В. Вплив застосування мікродобрив ТМ «Актив-харвест» на ріст, розвиток i врожайність рослин кукурудзи. Вісник Уманського національного університету садівництва. 2019. № 94(1). С.156-164. doi.org/10.31395/24158240-2019-94-1-156-164

14. Глушко Т. В., Войташенко Д. П. Урожайність та якість зерна кукурудзи під впливом біопрепаратів в умовах зрошення Південного Степу України. Зрошуване землеробство. 2013. № 59. С. 44-47.

15. Науково-практичні рекомендації 3 технології вирощування кукурудзи в умовах зрошення Південного Степу України. Херсон: Грінь Д.С., 2015. 104 c.

16. Вожегова Р. А., Лавриненко Ю. О., Малярчук М. П. Методика польових і лабораторних досліджень на зрошуваних землях. Херсон: Грінь Д.С., 2014. 286 с.

17. Ушкаренко В. О., Нікішенко В. Л., Голобородько С. П., Коковіхін С. В. Дисперсійний і кореляційний аналіз результатів польових дослідів Херсон: Айлант, 2009. 372 с.

\section{Information about the author:} Marchenko T. Yu., Candidate (Ph.D.) of Agricultural Sciences, Senior Researcher, Head of the Plant Breeding Department,

Institute of Irrigated Agriculture of the National Academy of Agrarian Sciences of Ukraine Kherson, Naddniprianske, 73483, Ukraine 